DOI: 10.4274/tod.67699

Turk J Osteoporos 2017;23:67-9

\title{
Postpartum Unilateral Sacral Stress Fracture Mimicking Lumbar Radiculopathy: Case Report
}

\author{
Lomber Radikülopatiyi Taklit Eden Postpartum Unilateral Sakral Stres Kırığı: Olgu Sunumu \\ Sinan Bağçacı, Ali Yavuz Karahan* \\ Hakkari State Hospital, Clinic of Physical Medicine and Rehabilitation, Hakkari, Turkey \\ *Konya Training and Research Hospital, Clinic of Physical Medicine and Rehabilitation, Konya, Turkey
}

\section{Abstract}

Postpartum sacral stress fracture is a very rare clinical entity. Because of the ambiguous clinical and radiological findings, it is often diagnosed late. A case of a postpartal 25-year-old female patient presented with acute onset of low back pain radiating to the right extremity, mimicking lumbar radiculopathy. Magnetic resonance imaging of sacrum revealed a non-displaced stress fracture of the right sacral ala. The 25-hydroxy vitamine $\mathrm{D}$ level of the patient was very low; dual energy X-ray absorptiometry measurements were in the normal range. The patient is completely cured as a result of conservative treatment. As a result, sacrum stress fracture should be kept in mind in the presence of back pain during pregnancy and postpartum period.

Keywords: Sacral, postpartum, stress fracture

\section{Öz}

Postpartum sakral stres kırığı oldukça nadir bir klinik tablodur. Müphem klinik ve radyolojik bulgularının olması nedeniyle sıklıkla geç tanı almaktadır. Bu yazıda akut gelişen, lomber radikülopatiyi taklit eden ve belden sağ bacağa yayılan bir ağrı ile başvuran 25 yaşındaki postpartum dönmedeki kadın olgudan bahsedilmiştir. Manyetik rezonans görüntüleme ile hastada sakrumda alar bölgede displase olmamış stres kırı̆̆ı tespit edildi. Hastanın 25-hidroksi vitamin D düzeyi çok düşük iken; dual enerji X-ray absorsiyometri ölçümü normal aralıkta bulundu. Konservatif tedavi sonucunda hasta tamamen iyileşti. Sonuç olarak gebelikte ve postpartum dönemde hastalarda bel ağrısı varlığında sakrum stres kırı̆̆ı akılda tutulmalıdır.

Anahtar kelimeler: Sakral, postpartum, stres kırığı

\section{Introduction}

Complaints of low back pain and pain originating from sacroiliac joint are very common during pregnancy and postpartum period. So this commonness leads to a difficulty for the differential diagnosis of the significant etiologies and missed cases $(1,2)$. Sacral stress fracture is a very rare condition which may have many different clinical appearances. Up to now only a few cases have been reported in the literature describing the sacral stress fracture in the postpartum period. Clinical suspicion on this special diagnosis which may have important effects on patient quality of life should be increased.

\section{Case Report}

A 25-year-old female patient was admitted with acute onset of low back pain which had radiation to the right extremity till the foot. The pain was aggravating by standing and walking of the patient. In her medical history it was revealed that only a week ago she gave birth to a 3700 grams baby via spontaneous vaginal delivery. She had neither low back pain nor history of trauma or any constraint activity before. In the physical examination there was an antalgic gait pattern in addition to restricted and painful right hip rotation. Although straight-leg-raise was negative, sacroiliac joint was very painful

Address for Correspondence/ Yazışma Adresi: Sinan Bağçacı MD, Hakkari State Hospital, Clinic of Physical Medicine and Rehabilitation, Hakkari, Turkey Phone: +90 5307870834 E-mail: sinan18us@yahoo.com ORCID ID: orcid.org/0000-0002-9747-5082 Received/Geliş Tarihi: 31.08.2016 Accepted/Kabul Tarihi: 23.10.2017 


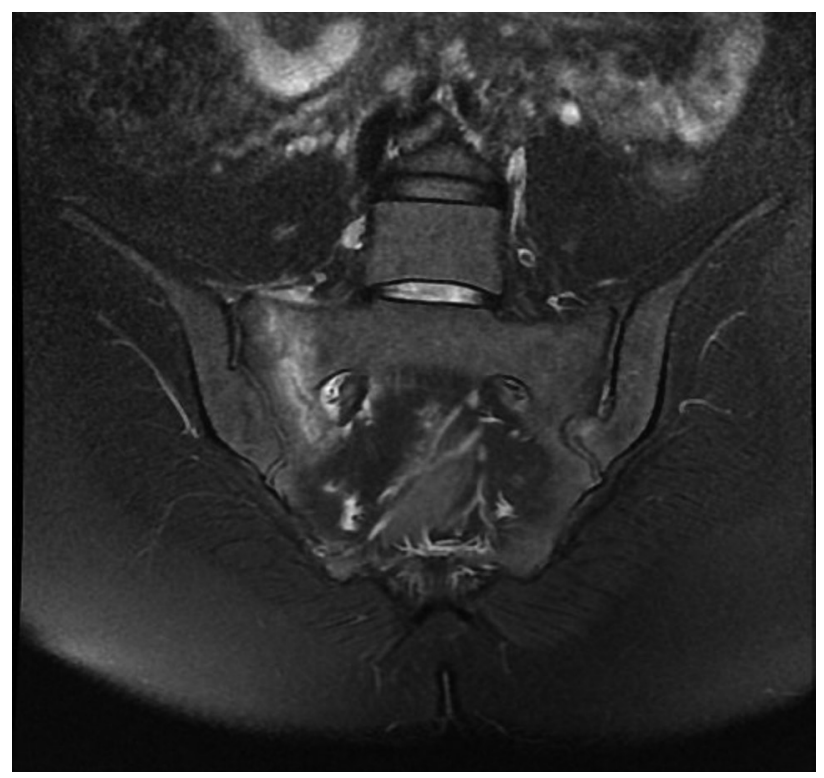

Figure 1. Sacroiliac joint magnetic resonance imaging: T2-weightened image shows the stress fracture in right sacral ala

with compression test at the right side. Direct radiographies of lumbar spine and pelvic bone were normal. Magnetic resonance imaging (MRI) of lumbar spine and sacroiliac joint showed a nondisplaced sacral stress fracture and osseous edema around it at the right side of sacral ala (Figure 1). Serum calcium, phosphorus and alkaline phosphate levels were all normal in addition to basic laboratory tests for renal, liver and thyroid functions except very low 25-hydroxy vitamin D level, as $4.8 \mathrm{ng} / \mathrm{mL}$ (normal range: $30-78 \mathrm{ng} / \mathrm{mL}$ ). After seeing normal $\mathrm{T}$ and $\mathrm{Z}$ scores in the bone mineral density measurement with dual energy X-ray absorptiometry, a treatment protocol consisting bed rest, pain control, supplementation of vitamin $\mathrm{D}$ and calcium suggested and accepted by patient. After three months of treatment she had no pain and her gait pattern was completely normal.

\section{Discussion}

Sacral stress fractures are very rare and most often occur in athletes. Sacral stress fracture during pregnancy and postpartum period is also a very rare entity. The possible mechanism blamed for sacral fractures of pregnancy and postpartum period is overloading during pregnancy and transient weakening of the bones seen in pregnancy. The differential diagnoses of fractures due to fatigue and or insufficiency is very difficult. Bone mineral density measurement was reported to be a helpful tool in this differentiation. A normal bone mineral density measurement with a very low 25-hydroxy vitamin D level gives an impression of weakness of the sacral bone related to very low 25-hydroxy vitamin D level (3-5)

The incidence of pregnancy-related osteoporosis is approximately 0.4/100.000 women.
The increased need for calcium, increased levels of progesterone and prolactin hormones, breast feeding besides mechanical changes such as the relaxation of pelvic and sacroiliac ligaments with increased relaxin, weight gaining, hyperlordotic posture, and sacral anterversion were all accused as the contributing factors for pregnancy-related osteoporosis. (6-8).

Generally, main clinical complaint of the patient is pain at low back, at the buttocks and sacroiliac joint. Pain usually worsens while standing and walking. Radicular symptoms are uncommon but may be present. Our patient had radicular pain pattern may be due to secondey nerve root compression or irritation. Denis et al. (9) classified the sacral fractures in two anatomic zones. Fractures of zone 1 involves ala of sacrum which could cause L5 root compression. L5 nerve root may be entrapped between $L 5$ transverse process ala of sacrum. It has been estimated that $2 \%$ of sacral fractures present with radicular symptoms. Our case had a zone 1 alar stress fractrure and had radicular symptoms (9). Why because radiography is generally normal, MRI is the best imaging method for these patients, which shows a typical fracture line including a vertical direction and edema surrounding the fracture. Our case also had a typical vertical fracture line (10).

The treatment options of the sacral stress fracture in pregnancy and postpartum period is limited and conservative treatment was generally chosen. If patient was diagnosed during pregnancy cesarean section should be preferred instead of spontaneous vaginal delivery that may worsen the sacral fracture. The case we presented here did not have a history of low back pain during pregnancy and just after the delivery. She had an uncomplicated spontaneous vaginal delivery and the role of it for sacral stress fracture is undetermined $(10,11)$.

This case is among the very few cases reported in the literature describing the sacral stress fracture in the postpartum period. Sacral stress fracture should be kept in mind in patients with low back pain during pregnancy and postpartum period because delays in diagnosis may cause secondary balance and skeletal system disorders. Besides, early diagnosis and appropriate treatment enhance the success of the treatment.

\section{Ethics}

Informed Consent: It was taken.

Peer-review: Internally peer-reviewed.

\section{Authorship Contributions}

Concept: S.B., A.Y.K., Design: S.B., A.Y.K., Data Collection or Processing: S.B., Analysis or Interpretation: S.B., A.Y.K., Literature Search: S.B., Writing: S.B., A.Y.K.

Conflict of Interest: The authors declared no conflicts of interest with respect to the authorship and/or publication of this article.

Financial Disclosure: The authors received no financial support for the research and/or authorship of this article. 


\section{References}

1. Sansone V, McCleery J, Bonoa C. Post-partum low-back pain of an uncommon origin: a case report. J Back Musculoskelet Rehabil 2013;26:475-7.

2. Narvaez J, Narvaez JA. Post-partal sacral fatigue fracture. Rheumatology (Oxford) 2003;42:384-5.

3. Schildhauer TA. Commentary on: "Atraumatic Sacral Fracture in Late Pregnancy: A Case Report". Global Spine J 2015;5:252.

4. Thienpont E, Simon JP, Fabry G. Sacral stress fracture during pregnancy-a case report. Acta Orthop Scand 1999;70:525-6.

5. Breuil V, Brocq O, Euller-Ziegler L, Grimaud A. Insufficiency fracture of the sacrum revealing a pregnancy associated osteoporosis. First case report. Ann Rheum Dis 1997;56:278-9.

6. Lin JT, Lutz GE. Postpartum sacral fracture presenting as lumbar radiculopathy: a case report. Arch Phys Med Rehabil 2004;85:1358-61.

7. Dussa CU, El Daief SG, Sharma SD, Hughes PL. Atraumatic fracture of the sacrum in pregnancy. J Obstet Gynaecol 2005;25:716-7.

8. De Búrca N. Low back pain post partum - a case report. Man Ther 2012;17:597-600.

9. Denis F, Davis S, Comfort T. Sacral fractures: an important problem. Retrospective analysis of 236 cases. Clin Orthop Relat Res 1988;227:67-81.

10. Oztürk G, Külcü DG, Aydoğ E. Intrapartum sacral stress fracture due to pregnancy-related osteoporosis: a case report. Arch Osteoporos 2013;8:139

11. Murray DJ, Bhatti W. Maternal sacral fracture during delivery causing foot drop. Int J Gynaecol Obstet 2011;115:289-90. 